\title{
Use of Molecular Markers (SSRs) and Public Databases in Vitis Vinifera L. as the Main Case of Efficient Crop Cultivar Identification
}

\author{
Francesco Panara ${ }^{1}$, Carlo Bergamini ${ }^{2}$, Alberto Palliotti ${ }^{3}$ and Ornella Calderini ${ }^{4 *}$ \\ ${ }^{1}$ ENEA, Trisaia Research Centre, Rotondella (MT) Italy \\ ${ }^{2}$ CREA VE, Turi (BA) Italy \\ ${ }^{3}$ DSA3, University of Perugia, Perugia Italy \\ ${ }^{4}$ CNR IBBR, Perugia Italy
}

Submission: June 05, 2018; Published: July 17, 2018

"Corresponding author: Calderini Ornella, CNR IBBR, via Madonna Alta 130, 06128 Perugia Italy, Tel: +390755014858;

E-mail: ornella.calderini@ibbr.cnr.it

Keywords: Biodiversity; Autochtonal grape varieties;Morphological descriptors; SSR Markers; Database

\section{Mini Review}

Grape (Vitis vinifera L.) is a main crop providing both fresh produce (table grape) and a main transformed beverage (wine) of ancient origin. It is grown in several countries in the world producing relevant business value as 8 million hectares of vineyards are estimated at the global level (http://www.fao. org/faostat). Despite the slowdown of the wine market after the financial crisis, the new century brought about a growth of $75 \%$ in volume and a doubling in value in 15 years in the international market [1].

Loss of biodiversity has occurred in grape as in many other crops because of the large cultivation of a limited number of highly productive and widely adapted cultivars, therefore the scientific community supported by different stakeholders has undertaken a large effort to preserve minor vines in different types of collections (at public institutions but also in private farms).

The number of existing grape cultivars is generally estimated as several thousands [2], however the Working Group on Vitis referring to the European Cooperative Programme for Plant Genetic Resources (ECPGR) reports 27,000 accessions of grape held only in European collections (first meeting, 2003) and in a second report (2012) the group is still seeking to solve the problem of cultivar synonyms and the presence of duplications in spite of the passport data available for about 35,000 accessions from European countries.
In general, local produce has gained a large appeal with consumers, this including local wines. Consumers perceive local foods as a mean to improve the sustainability of the system by reducing the carbon and water footprint and by providing new sale opportunities for local wineries, expecially of small-medium size. Marketing of traditional varieties is also exploiting the perception of consumers to be part of biodiversity conservation connected to historical aspects of the region and it uses adjectives such as "indigenous, rare, neglected, recovered". Concerning grape, the development of oenotourism has raised awareness in consumers of the so-called terroir and the request of local wines produced using autochthonal grape varieties. In addition, there is a general trend to drink wines with a lower alcohol and phenolics content which is typical of older varieties [3].

In view of the large number of vines reported worldwide a proper identification system is necessary. The aims of plant variety identification are several including breeding programs, cultivar registration and protection and subsequently its seed (or cutting) production and trade. Cultivar identification is usually addressed via morphological descriptors and (more recently) molecular markers. Discrimination between varieties within a species may be difficult. PBR/PVR registration requires varieties to be morphologically distinct, uniform and stable (DUS) [4], however field trials and testing for varietal identification or verification based on morphological criteria may be costly and time-consuming. Environmental factors can influence 
the expression of morphological characteristics, thus causing variation between environments and across years.

Morphological descriptors have been used for many years in grape cultivar identification and they have been coded by the Organization Internationale de la Vigne et du Vin (OIV) for more than 600 different traits (2nd Edition of the OIV Descriptor list for grape varieties and Vitis species). Ampelography is the term of use to refer to grape morphological analysis as a science to distinguish grapevines from a phenotypical point of view [5]. In more recent times softwares such as Superampelo have been developed to aid the morphological scoring assisted by Image analysis [6]. Interestingly a morphometric analysis of leaf shape via Elliptical Fourier Descriptors (EFD) and generalized Procrustes analysis combined to Genome Wide Association Analysis (GWAS) of 1,200 USDA cultivars allowed the discovery of genomic regions associated to leaf morphological traits [7].

Recently, molecular markers based on DNA, have become an essential tool for genotyping and therefore for the identification of plant (grape) varieties. Molecular markers have the advantage of being stable and independent from the environmental conditions compared to morphological descriptors. Among the several types of markers (reviewed recently in [8]) the grape scientific community has chosen Simple Sequence Repeats (SSR) for cultivar identification because of their combination of polymorphism, reproducibility, and their codominant nature $[9,10]$. Two European projects (Genres081/GrapeGen06) allowed the same community to agree on a set of 6 SSR markers (VVS2, VVMD5, VVMD7, VVMD27, VrZag62, VrZag79) added to the OIV register in 2009 which were lately increase of 3 more (VVMD25, VVMD28 e VVMD32) as reported in Table 1. Alleles are conveniently expressed as relative base pair distance to the shortest allele size (n) found within the Genres081. It is considered that two different plants having the same profile for the 9 SSR loci represent the same grape genotype. The mentioned SSR set is not able to distinguish among somatic variants which are common in grape as natural mutations occurring because of the vegetative type of propagation; those showing modifications in major traits can be commercialized as new cultivars and their identification is of economic importance.

Table 1: SSR markers adopted by the international scientific community as diagnostic for the identity of two grape plants.

\begin{tabular}{|c|c|c|c|}
\hline OIV Code & SSR Marker & Size Range & Largest known Allele \\
\hline OIV 801 & SSR-marker VVS2 & $123 / 124-161 / 162$ & $\mathrm{n}+38$ \\
\hline OIV 802 & SSR-marker VVMD5 & $222-268$ & $\mathrm{n}+46$ \\
\hline OIV 803 & SSR-marker VVMD7 & $231-265$ & $\mathrm{n}+34$ \\
\hline OIV 804 & SSR-marker VVMD27 & $171-219$ & $\mathrm{n}+44$ \\
\hline OIV 805 & SSR-marker VrZAG62 & $174-220$ & $\mathrm{n}+46$ \\
\hline OIV 806 & SSR-marker VrZAG79 & $235 / 236-261 / 262$ & $\mathrm{n}+26$ \\
\hline OIV 807 & SSR-marker VVMD25 & $235-271$ & $\mathrm{n}+36$ \\
\hline OIV 808 & SSR-marker VVMD28 & $216-280$ & $\mathrm{n}+64$ \\
\hline OIV 809 & SSR-marker VVMD32 & $235-292$ & $\mathrm{n}+57$ \\
\hline
\end{tabular}

The important step undertaken by the grape community was to establish public databases that store the OIV descriptors with a particular focus on the SSR data. Every laboratory can undertake cultivar analysis by using a reference cultivar from the database itself to adjust the length of the 9 SSRs, such length in fact may vary of few bases due to experimental error depending on laboratory conditions. Databases accept novel SSR data after proper standardization. There are a few databases available as reported in Table 2. Many thousand genotypes are stored and by standardization of the analysis it is possible to compare the SSR profile of an unknown vine to have the chance to verify its identity; it is worth mentioning that SSR profiles are updated constantly.

Table 2: List of Vitis sp. databases storing information's on several characters (ampelographic, molecular markers etc.).

\begin{tabular}{|c|c|c|}
\hline Database & Features & Link \\
\hline Vitis International Variety Catalogue (VIVC) & $\begin{array}{c}\text { SSR profiles at } 9 \text { loci for } 3675 \text { genotypes } \\
\text { available }\end{array}$ & http://www.vivc.de \\
\hline European Vitis Database & $\begin{array}{l}\text { SSR profiles at } 9 \text { loci for } 4315 \text { genotypes } \\
\text { available; } n+x \text { OIV coding is used; registering } \\
\text { for database access is required }\end{array}$ & http://www.eu-vitis.de \\
\hline Registro Nazionale delle Varietà di Vite & $\begin{array}{l}\text { SSR profiles at } 12 \text { loci for } 554 \text { genotypes } \\
\text { available; } n+x \text { OIV coding is used }\end{array}$ & $\begin{array}{l}\text { http://catalogoviti.politicheagricole.it/ } \\
\text { catalogo.php }\end{array}$ \\
\hline Italian Vitis Database & & http://www.vitisdb.it \\
\hline Swiss Vitis Microsatellite Database & $\begin{array}{l}\text { SSR profile for the vines grown in } \\
\text { Switzerland, approx. } 170 \text { genotypes }\end{array}$ & http://www1.unine.ch/svmd \\
\hline $\begin{array}{l}\mathrm{Pl} @ \text { nt grape - Le catalogue des } \\
\text { vignescultivéesen France }\end{array}$ & SSR profiles at 9 loci & $\begin{array}{c}\text { http://plantgrape.plantnet-project.org/it/ } \\
\text { cepages }\end{array}$ \\
\hline
\end{tabular}




\begin{tabular}{|c|c|c|}
\hline RéseauFrançais de Conservatoires de Vigne & registering for database access is required & $\begin{array}{c}\text { https://bioweb.supagro.inra.fr/collections_ } \\
\text { vigne/Home.php }\end{array}$ \\
\hline $\begin{array}{c}\text { Nat'l Clonal Germplasm Rep - Tree Fruit \& Nut } \\
\text { Crops \& Grapes: Davis, CA- USA }\end{array}$ & SSR profiles at 8 loci for 224 genotypes & $\begin{array}{c}\text { https://www.ars.usda.gov/pacific-west-area/ } \\
\text { davis-ca/natl-clonal-germplasm-rep-tree- } \\
\text { fruit-nut-crops-grapes/docs/grape-ssr- } \\
\text { fingerprinting/main/ }\end{array}$ \\
\hline
\end{tabular}

In Italy the CREA-VE Center at Conegliano Veneto (TV) offers a service of grape identification (http://sito.entecra.it/ portale/cra_avviso.php?id=13755\&tipo=\&lingua=IT) based on an updated core set of 11 SSRs and analysis of its own database of genotypes [11]. The new SSR toolkit can distinguish somatic variants with particular reference to berry colour [12].

Given the large effort of the international scientific grape community to collect, standardize and share several types of cultivar descriptors, we envisage grape as the main crop whose cultivar identification is best coded and approachable by smallmedium size laboratories at the molecular level.

\section{References}

1. Pomarici E (2016) Recent trends in the international wine market and arising research questions. Wine Economics and Policy 5: 1-3

2. Jackson RS (1994) Wine science. Principles and applications. Academic Press, Canada, pp.59.

3. Panara F, Petoumenou D, Calderini O, Dini F, D'Onofrio C, et al. (2015) Ampelographic and genetic characterisation of ancestral grapevine (Vitis vinifera L.) accessions present in the Umbria Region (Centra Italy). The Journal of Horticultural Science and Biotechnology 88(5): 525-530.

4. UPOV at http://www.upovint/about/en/upov_system. html\#P177_18977.

This work is licensed under Creative

Commons Attribution 4.0 License

DOI: 10.19080/JOJHA.2018.01.555576
5. Galet P (1952) Précis d'AmpélographiePratique. Impr. P. Déhan, Montpellier, France.

6. Soldavini C, Stefanini M, Dallaserra M, Policarpo M, Schneider A (2009) Superampelo, a software for ampelometric and ampelographic descriptions in Vitis. Acta Horticulturae 827: 253-258.

7. Chitwood DH, Ranjan A, Martinez CC, Headland LR, Thiem T, etal. (2013) A modern ampelography: a genetic basis for leaf shape and venation patterning in Vitis vinifera. Plant Physiology 164(1): 259-272.

8. Grover A, Sharma PC (2014) Development and use of molecular markers: past and present. Critical Review in Biotechnology 1-13.

9. Sefc KM, Lefort F, Grando MS, Scott KD, Steinkellner H et al. (2001) Microsatellite Markers for Grapevine: A State of the Art. RoubelakisAngelakis KA (ed.), Grapevine Molecular Physiology \& Biotechnology, $2^{\text {nd }}$ edn., Springer Science+Business Media B.V.

10. This P, Jung A, Boccacci P, Borrego J, Botta R, et al. (2004) Development of a standard set of microsatellite reference alleles for identification of grape cultivars. Theoretical and Applied Genetics 109(7): 1448-1458.

11. Crespan M, Bavaresco L, Migliaro D (2014) I microsatelliti per identificare le varietà. Informatore Agrario 4: 30-32.

12. Migliaro D, De Nardi B, Vezzulli S, Crespan M (2017) An Upgraded Core Set of 11 SSR Markers for Grapevine Cultivar Identification: The Case of Berry Color Mutants. Am J Enol Vitic 68: 496-498.

Your next submission with Juniper Publishers
will reach you the below assets
- Quality Editorial service
- Swift Peer Review
- Reprints availability
- E-prints Service
- Manuscript Podcast for convenient understanding
- Global attainment for your research
- Manuscript accessibility in different formats
( Pdf, E-pub, Full Text, Audio)
- Unceasing customer service
Track the below URL for one-step submission
https://juniperpublishers.com/online-submission.php

